\title{
Psihologija tretjega življenjskega obdobja Vid Pečjak
}

$P_{r}$ ne le strokovnih psiholoških del, ampak tudi leposlovne literature, je svoje zadnje delo namenil raziskovanju psihologije starejših. Knjiga je v samozaložbi in delno s pomočjo Znanstvenega inštituta Filozofske fakultete v Ljubljani izšla leta 1998.

Knjiga je poleg predgovora, $\mathrm{v}$ katerem avtor pojasnjuje svoj odnos do starosti in staranja, in uvoda $\mathrm{z}$ orisom značilnosti tretjega življenjskega obdobja sestavljena iz treh poglavij. V prvem z naslovom Telo avtor opiše biološke zakonitosti in značilnosti staranja (evolucijski pogled na staranje, življenjska doba vrst in posameznikov, biološke teorije staranja, starostna samopodoba, staranje notranjih organov, vloga prehranjevanja). V drugem poglavju, naslovljenim z Družba, avtor oriše staranje s sociološkega zornega kota in tu spregovori o starostnih stereotipih in odnosu družbe do starejših, o ageizmu, o posledicah upokojitve ter o spremembi vlog znotraj družine, ki pogosto nastopijo $\mathrm{v}$ tretjem življenjskem obdobju. V tretjem delu knjige $\mathrm{z}$ naslovom Duša pa avtor izčrpno opiše psihološke značilnosti staranja. Tako predstavi upad čutnih sposobnosti v starosti, spregovori o gibalnih sposobnostih in vlogi športa pri starejših. Nadalje seznani bralca z nekaterimi pomembnimi raziskavami o umskih sposobnostih in ustvarjalnosti ter o delovnih sposobnostih starostnikov ter o modrosti, ki je pridobitev mnogih različnih življenjskih izkušenj in je v tej življenjski dobi najbolj pogosta. Govori še o emocijah, motivaciji, o spolnosti ter o sanjah $\mathrm{v}$ tem obdobju, spregovori pa tudi o demenci in še nekaterih drugih hudih težavah, ki prizadenejo nekatere starejše.

Knjiga prinaša izsledke najsodobnejših raziskav o staranju in starosti, njena posebna odlika pa je v tem, da avtor ob nekaterih po-

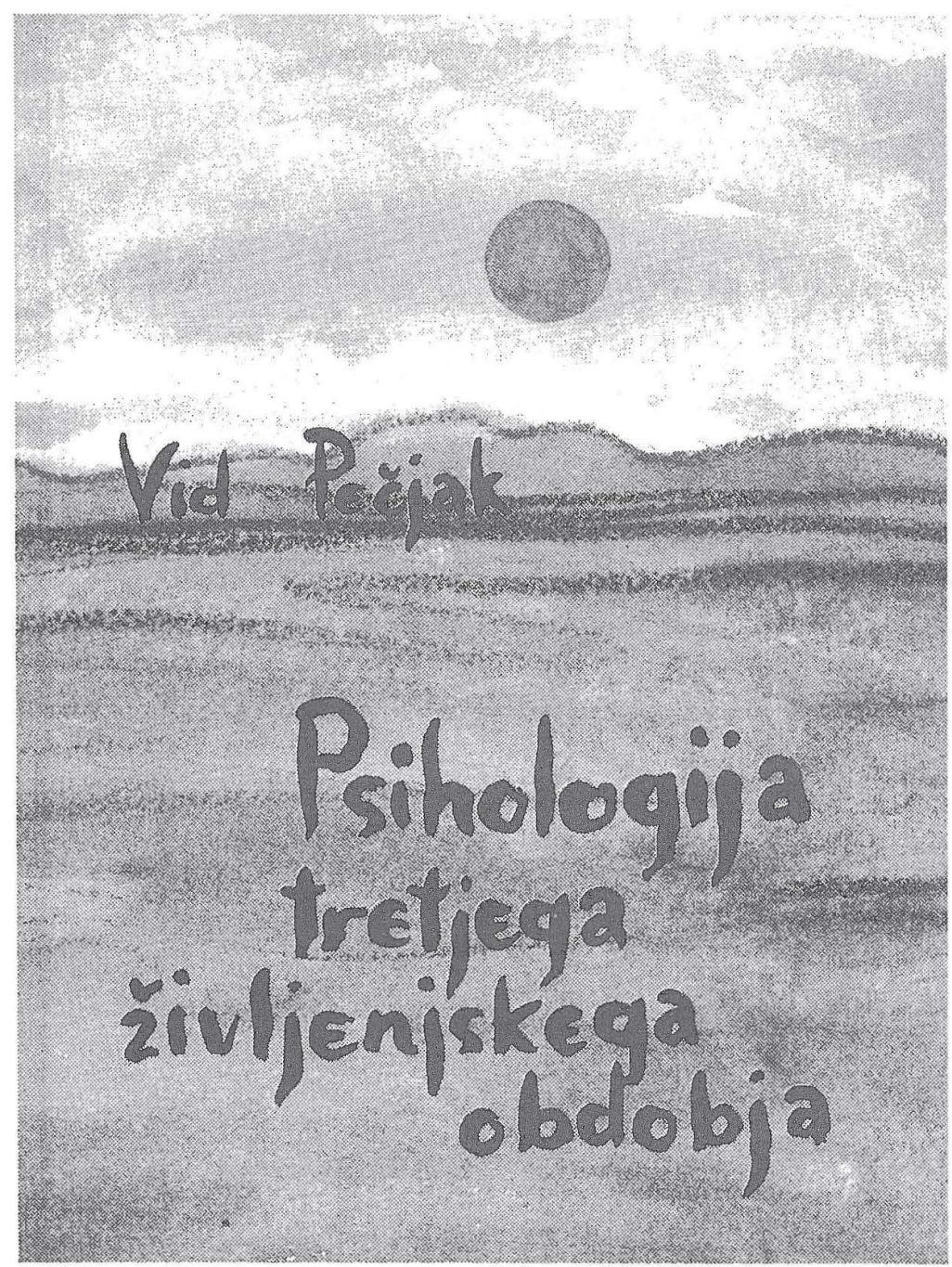

glavjih bralcu ponuja tudi praktične napotke in recepte za trening ohranjanja določenih sposobnosti.

Tretje življenjsko obdobje postaja tema, o kateri se vse več govori, in knjiga je več kot aktualna ne le za starejše, temveč tudi za širši krog bralcev in prav tako za širok spekter strokovnjakov, ki se pri svojem delu srečujejo $\mathrm{s}$ starejšimi in fenomenom staranja.

Pripravila: Tanja Sulak

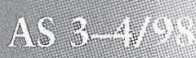

